\title{
PENGAWASAN BERPENGARUH TERHADAP KINERJA PEGAWAI PADA KANTOR CAMAT KECAMATAN PLAKAT TINGGI
}

\author{
Oleh : \\ Fery Supriyanto \\ ferycw80@gmail.com \\ STIE Rahmaniyah Sekayu
}

J1. Merdeka No. 531 Kel. Serasan Jaya Kec. Sekayu (30711)

\begin{abstract}
The purpose of this study is to see the Effect of Supervision toward Employee Performance at sub-district Office of Plakat Tinggi Musi Banyuasin Regency. The theoretical basis that the author used were Definition of Management, Definition of Human Resource Management, Definition of Supervision, Monitoring Indicators, Supervision Objectives, Types of Supervision, Engineering Supervision, Performance Definition, Performance Indicators, Performance Affecting Factors, Performance Assessment, Objectives and Benefits of Assessment Performance, and Performance Appraisal Criteria. Dependent variable used in this research was Employee Performance and independent variable was supervision. Populations and samples in this study were 30 employees. The author used data collection techniques by using questionnaires, documentation and observation. Data analysis techniques used simple linear regression analysis. This study found that Supervision had a positive and significant influence toward Employees Performance at the Sub-district office of Plakat Tinggi.
\end{abstract}

Keywords: supervision and performance of employees.

\begin{abstract}
ABSTRAK
Tujuan penelitian ini adalah untuk melihat Pengaruh Pengawasan Terhadap Kinerja Pegawai Pada Kantor Camat Plakat Tinggi Kabupaten Musi Banyuasin. Landasan teori yang penulis gunakan adalah Definisi Manajemen, Pengertian Manajemen Sumber Daya Manusia, Pengertian Pengawasan, Indikator Pengawasan, Tujuan Pengawasan, Tipe-Tipe Pengawasan, Teknik Pengawasan, Definisi Kinerja, Indikator Kinerja, Faktor yang Mempengaruhi Kinerja, Penilaian Kinerja, Tujuan dan Manfaat Penilaian Kinerja, dan Kriteria Penilaian Kinerja. Variabel dependen yang digunakan dalam penelitian ini adalah Kinerja Pegawai dan variabel independennya adalah pengawasan. Populasi dan sampel dalam penelitian ini berjumlah 30 orang pegawai. Penulis menggunakan teknik pengumpulan data dengan cara kuisioner, dokumentasi dan observasi. Teknik analisis data menggunakan analisis regresi linier sederhana. Penelitian ini menemukan bahwa Pengawasan memiliki pengaruh yang posistif dan signifikan terhadap Kinerja Pegawai pada Kantor Camat Plakat Tinggi.
\end{abstract}

Kata Kunci:pengawasan dan kinerja pegawai. 


\section{PENDAHULUAN}

Aspek manajemen suatu organisasi diperlukan untuk mencapai tujuan dari pada organisasi secara optimal. Selain itu pula pengawasan merupakan salah satu fungsi manajemen yang harus dilakukan untuk menjaga agar pelaksanaan kegiatan sesuai dengan rencana yang telah ditetapkan dalam rangka pencapaian tujuan. Menurut Draft (2012:6), pengawasan (controlling) adalah memonitor aktivitas karyawan, menentukan apakah organisasi sejalan dengan tujuannya. Dengan adanya pengawasan dapat diperoleh informasi mengenai kinerja pegawai dalam pencapaian tujuan yang diharapkan dan informasi tersebut dapat digunakan untuk penyempurnaan kegiatan dan pengambilan keputusan oleh pimpinan.

Kinerja pegawai yang tinggi dibutuhkan kemampuan dari pimpinan untuk memperhatikan hubungan antar pegawai yang tentunya akan mengarah kepada pembinaan para pegawai, sehingga pegawai dapat pula memahami tugas dan tanggung jawab masing-masing serta mematuh iaturan-aturan yang telah ditetapkan sebelumnya dan demikian tentunya akan berpengaruh pada peningkatan kinerja pegawai. Menurut Rivai dkk (2014: 406), kinerja merupakan tingkat pencapaian hasil atas pelaksanaan tugas tertentu. Sehubungan dengan sifat dari pekerjaan serta keadaan yang selalu berkembang sebagai akibat tuntutan pelaksanaan pembangunan agar berjalan tertib dan lancar maka diperlukan pegawai yang benar-benar cakap, disiplin, terampil dan tangguh dalam melaksanakan tugas dan pekerjaannya.

Kantor Camat Plakat Tinggi adalah sebuah lembaga instansi pemerintahan yang dipimpin oleh Camat dan dibantu oleh beberapa Seksi untuk menjalankan pemerintahan diwilayah kecamatan sebagai organisasi publik dan pelayan masyarakat. Camat merupakan Perangkat Daerah Kabupaten dan Daerah Kota yang berada diatas Kelurahan. Sebagai seorang Camat salah satu tugasnya adalah mengawasi seluruh pegawainya supaya dapat bekerja secara efektif dan efisien. Pengawasan yang dilakukan oleh Camat tentunya akan sangat mempengaruhi kinerja setiap pegawai yang bekerja pada Kantor Camat Kecamatan Plakat Tinggi yang berada diwilayah Kabupaten Musi Banyuasin. 
Setiap instansi khususnya Kantor Camat Plakat Tinggi tentunya menginginkan agar pegawai yang berada disetiap instansi memiliki kinerja yang tinggi dari setiap pegawai, akan tetapi pada kenyataannya masih ada pegawai yang memiliki kinerja yang rendah.

Berdasarkan pengamatan terdapat fenomena yaitu sebagian pegawai datang tidak tepat waktu, masih adanya sebagian pegawai yang meninggalkan kantor disaat jam kerja, dan dalam melaksanakan tugas yang diberikan sering kali diselesaikan tidak tepat waktu, kesemuanya ini tentu akan menghambat pencapaian tujuan dan menimbulkan efek negatif bagi kantor Camat Kecamatan Plakat Tinggi. Fenomena diatas tersebut mencerminkan bahwa kinerja pegawai dikantor Camat Kecamatan Plakat Tinggi masih rendah dan pengawasannya belum optimal sebagaimana yang diharapkan.

Berdasarkan latar belakang masalah yang dikemukakan diatas, maka peneliti berminat mengkaji tentang "PENGARUH PENGAWASAN TERHADAP KINERJA PEGAWAI PADA KANTOR CAMAT KECAMATAN PLAKAT TINGGI”.

\section{TINJAUAN PUSTAKA}

\section{Pengertian Manajemen}

Menurut Draft (2012:6), manajemen adalah pencapaian tujuan-tujuan organisasional secara efektif dan efisien melalui perencanaan ,pengelolaan, kepemimpinan, dan pengendalian sumberdaya-sumberdaya organisasi. Terdapat empat fungsi manajemen menurut Draft yaitu perencanaan, pengelolaan, kepemimpinan dan pengendalian.
a. Perencanaan
Perencanaan (planning) yaitu mengidentifikasi berbagai tujuan untuk kinerja organisasi dimasa mendatang serta memutuskan tugas dan penggunaan sumberdaya yang diperlukan untuk mencapainya.
b. Pengelolaan
Pengelolaan biasanya dilakukan setelah perencanaan dan mencerminkan bagaimana organisasi mencoba mewujudkan perencanaan. Pengelolaan (organizing) mencakup menentukan tugas, mengelompokkan tugas dan mengalokasikan sumberdaya didalam organisasi.
c. Kepemimpinan
Kepemimpinan (leading) bararti menggunakan pengaruh untuk memotivasi pegawai guna mencapai tujuan-tujuan organisasi. Kepemimpinan berarti menciptakan nilai- 
nilai dan budaya, mengkomunikasikan tujuan-tujuan pegawai diorganisasi, dan menyuntikkan semangat untuk memperlihatkan kinerja tertinggi kepada pegawai.

d. Pengendalian

Pengendalian adalah fungsi keempat dari proses manajemen. Pengendalian (controlling) adalah memonitor aktivitas pegawai, menentukan apakah organisasi sejalan dengan tujuannya, dan membuat koreksi jika diperlukan. Para pimpinan harus memastikan bahwa organisasi mereka bergerak menuju tujuan-tujuannya.

\section{Pengertian Manajemen Sumber Daya Manusia}

Sumber Daya Manusia (SDM) adalah salah satu faktor yang sangat penting bahkan tidak dapat dilepaskan dari sebuah organisasi, baik instansi maupun perusahaan. Karena SDM merupakan kunci keberhasilan bagi setiap instansi. Pada hakikatnya SDM berupa manusia yang dipekerjakan disebuah organisasi sebagai penggerak untuk mencapai tujuan organisasi itu. Untuk menggerakkan sumber daya manusia tidaklah mudah diperlukan suatu pengawasan agar apa yang menjadi tujuan organisasi bisa tercapai, dan suatu pengawasan juga dibutuhkan untuk meningkatkan kinerja sumber daya manusia dalam suatu instansi.

Bangun (2012:5), menjelaskan bahwa untuk mendefinisikan manajemen sumber daya manusia, perlu pemahaman pada dua fungsi antara lain fungsi-fungsi manajerial (managerial Functions) dan operasional (operational functions). Fungsi sumber daya manusia yaitu perencanaan, pengorganisasian, penyusunan staf, penggerakan dan pengawasan terhadap fungsi-fungsi operasionalnya, untuk mencapai tujuan organisasi. Fungsi operasional manajemen sumber daya manusia berkaitan dengan pengelolaan manusia dalam organisasi, seperti pengadaan, pengembangan, pemberian kompensasi, pengintegrasian, pemeliharaan dan pemisahan tenaga kerja

Sutrisno (2013:7), mendefinisikan manajemen sumber daya manusia sebagai suatu perencanaan, pengorganisasian, pengarahan, dan pengawasan atas pengadaan, pengembangan, kompensasi, pengintegrasian, pemeliharan dan pemutusan hubungan kerja dengan maksud untuk mencapai tujuan organisasi. Menurut Rivai dkk (2014:4), manajemen sumber daya manusia merupakan salah satu bidang dari manajemen umum yang meliputi segi-segi perencanaan, pengorganisasian, pelaksanaan dan pengendalian. 
Berdasarkan beberapa pendapat diatas maka dapat disimpulkan bahwa definisi dari manajemen sumber daya manusia tersebut adalah suatu proses pengendalian, baik itu dari segi perencanaan, pengorganisasian, dan pengarahan, serta sampai pada pengawasan sumber daya manusia dalam mengatur hubungan dan peranan tenaga pegawai agar lebih efektif dan efisien dalam pencapaian tujuan.

\section{Pengertian Pengawasan}

Pengawasan merupakan fungsi manajerial yang keempat setelah perencanaan, pengorganisasian, dan pengarahan sebagai salah satu fungsi manajemen. Mekanisme pengawasan dalam suatu instansi memang diperlukan, pelaksanaan suatu rencana atau program tanpa diiringi dengan suatu sistem pengawasan yang baik dan berkesinambungan jelas akan mengakibatkan lambatnya atau bahkan tidak tercapainya sasaran dan tujuan yang telah ditentukan. Sehingga pada perkembangan pengawasan semakin mendapat perhatian dari suatu instansi.Instansi semakin menyadari pentingnya pengawasan sebagaisalah satu kesuksesan. pengawasan dilakukan guna meningkatkan kinerja pegawai dalam suatu organisasi.

Pengawasan menurut Engkoswara (2011:219), adalah suatu proses untuk mengetahui ada tidaknya penyimpangan dalam pelaksanaan rencana, jika ada penyimpangan agar segera dilakukan upaya perbaikan sehingga dapat memastikan bahwa aktifitas yang dilaksanakan secara riel merupakan aktifitas yang sesuai dengan apa yang direncanakan.

Siagian (2007:55), menyatakan bahwa pengawasan adalah keseluruhan upaya pengamatan pelaksanaan kegiatan operasional guna menjamin bahwa kegiatan tersebut sesuai dengan rencana yang telah ditetapkan sebelumnya. Tujuan utama dari pengawasan yaitu mengusahakan supaya apa yang direncanakan menjadi kenyataan dan mencari serta memberitahu kelemahan-kelemahan yang dihadapi. Jadi dalam setiap kegiatan yang akan diselenggarakan, pengawasan selalu dibutuhkan. Dengan adanya pengawasan yang baik diharapkan rencana atau tujuan yang telah ditetapkan akan dapat terjadi dengan cara yang efektif dan efisien. Karena melalui pengawasan diusahakan agar setiap tindakan atau perbuatan tidak menyimpang dari ketentuan-ketentuan yang ada. 
Solihin (2009:193), juga berpendapat bahwa pengawasan (controlling) merupakan proses monitoring terhadap berbagai aktivitas yang dilakukan sumber daya organisasi untuk memastikan bahwa aktivitas yang dilakukan tersebut bisa mencapai tujuan yang telah ditetapkan dan tindakan koreksi dapat dilakukan untuk memperbaiki penyimpangan yang terjadi.

Dari beberapa pendapat diatas dapat disimpulkan bahwa pengawasan merupakan suatu kegiatan yang mengusahakan agar suatu pekerjaan terlaksana sesuai dengan rencana, standar dan hasil kerja yang telah ditetapkan.

\section{Indikator Pengawasan}

Menurut Handoko (2009: 70), indikator pengawasan yaitu:

1. Menentukan Standar Kerja, Yaitu menetapkan ukuran standar pelaksanaan, standar mengandung arti sebagai suatu satuan pengukuran yang dapat digunakan sebagai patokan untuk penilaian hasil-hasil.

2. Pengukuran Hasil Kerja, Yaitu suatu pengukuran yang dilakukan oleh pengawas dengan melihat hasil kerjanya dan laporan tertulisnya.

3. Mengadakan Perbaikan atau Pembetulan, Yaitu adanya perbaikan atau pembetulan atas penyimpangan yang terjadi, sehingga pekerjaan yang dikerjakan sesuai dengan apayang direncanakan.

\section{Tujuan Pengawasan}

Pelaksanaan kegiatan untuk mencapai tujuan yang telah ditetapkan memerlukan pengawasan agar perencanaan yang telah disusun dapat terlaksana dengan baik. Pengawasan dikatakan sangat penting karena pada dasarnya manusia sebagai objek pengawasan mempunyai sifat salah dan khilaf. Oleh karena itu manusia dalam organisasi perlu diawasi, bukan untuk mencari kesalahannya kemudian menghukumnya, tetapi mendidik dan membimbingnya. Menurut Hasibuan (2008:241), tujuan pengawasan yaitu:

1. Supaya proses pelaksanaan dilakukan sesuai dengan ketentuan-ketentuan yang telah direncanakan.

2. Untuk melakukan tindakan perbaikan, jika dalam pelaksanaannya terdapat penyimpangan-penyimpangan.

3. Supaya rencana yang ditetapkan sesuai dengan tujuan.

\section{Tipe-tipe Pengawasan}


Handoko juga membagi tiga tipe pengawasan (2009: 74), yaitu:

a. Pengawasan Pendahuluan

Pengawasan pendahuluan sering disebut freedforwardcontrol, dirancang untuk mengantisipasi masalah atau penyimpangan dari suatu standar atau tujuan serta memungkinkan koreksi dibuat sebelum suatu tahap kegiatan tertentu diselesaikan. Jadi, pengawasan ini lebih aktif dan agresif dengan mendeteksi masalah dan mengambil suatu tindakan yang diperlukan sebelum masalah muncul atau terjadi. Pengawasan ini bersifat preventif artinya tindakan pencegahan sebelum munculnya suatu permasalahan atau penyimpangan.

b. Pengawasan Selama Kegiatan Berlangsung

(Concurrent Control)

Pengawasan ini dilakukan bersamaan dengan pelaksanaan kegiatan. Pengawasan ini merupakan proses dimana aspek tertentu dari suatu prosedur disetujui terlebih dahulu sebelum kegiatan-kegiatan dilanjutkan.

c. Pengawasan Umpan Balik (Feedback Control)

Pengawasan ini bertujuanuntuk mengukur hasil dari suatu kegiatan yang telah diselesaikan. Sebab-sebab dari penyimpangan atau kesalahan dicaritahu kemudian penemuan-penemuan tersebut dapat diterapkan pada kegiatan-kegiatan yang serupa dimasa yang akan datang. Pengawasan ini bersifat historis, pengukuran dilakukan setelah kegiatan terjadi

\section{Teknik Pengawasan}

Dalam melakukan pengawasan, perlu ditetapkan teknik-teknik pengawasan tertentu agar pengawasan itu sendiri dapat berlangsung secara efektif dan efisien. Untuk melaksanakan pengawasan, dapat dilakukan teknik pengawasan. Siagian (2007:60), menyatakan terdapat dua teknik pengawasan yaitu:

1. Pengawasan langsung, yaitu pemimpin organisasi mengadakan sendiri pengawasan terhadap kegiatan yang sedang dijalankan. Pengawasan langsung ini dapat berbentuk observasi yang dilakukan oleh pemimpin kepada pegawainya.

2. Pengawasan tidak langsung yaitu pengawasan dari jarak jauh, pengawasan ini dilakukan melalui laporan yang disampaikan oleh bawahan. Laporan ini dapat tertulis dan lisan melalui telepon.

\section{Pengertian Kinerja}

Bangun (2012:231), berpendapat bahwa kinerja (performance) adalah hasil pekerjaan yang dicapai seseorang berdasarkan persyaratan-persyaratan pekerjaan.Suatu pekerjaan mempunyai persyaratan tertentu untuk dapat dilakukan dalam mencapai tujuan. Tika (2006:121), menjelaskan kinerja sebagai hasil-hasil fungsi pekerjaan atau 
kegiatan seseorang atau kelompok dalam suatu organisasi yang dipengaruhi oleh berbagai faktor untuk mencapai tujuan organisasi dalam periode waktu tertentu.

Menurut Mangkunegara (2006:9), bahwa kinerja sumber daya manusia adalah prestasi kerja atau hasil kerja (output)baik kualitas maupun kuantitas yang dicapai sumber daya manusia persatuan periode waktu dalam melaksanakan tugas kerjanya sesuai dengan tanggung jawab yang diberikan kepadanya. Rivai dkk (2014:406), menyatakan kinerja merupakan tingkat pencapaian hasil atas pelaksanaan tugas tertentu. Sedangan manajemen kinerjaadalah keseluruhan kegiatan yang dilakukan untuk meningkatkan kinerja perusahaan atau instansi, termasuk kinerja masing-masing individu dan kelompok kerja diorganisasi tersebut.

Berdasarkan pendapat diatas dapat diartikan bahwa kinerja adalah kemampuan dan hasil kerja yang diperlihatkan karyawan dalam melaksanakan tugas dan kewajibannya menurut ukuran yang berlaku atau yang ditetapkan untuk pekerjaan yang bersangkutan.

\section{Indikator Kinerja}

Bangun (2012:233), menjelaskan ada enam indikator untuk mengukur kinerja melalui:

1. Jumlah Pekerjaan. Setiap pekerjaan harus memiliki persyaratan yang berbeda sehingga menuntut pegawai harus memenuhi persyaratan tersebut baik pengetahuan, keterampiln, maupun kemampuan yang sesuai. Berdasarkan persyaratan pekerjaan tersebut dapat diketahui jumlah pegawai yang dibutuhkan untuk dapat mengerjakannya, atau setiap pegawai dapat mengerjakan beberapa unit pekerjaan.

2. Kualitas Pekerjaan. Setiap pekerjaan mempunyai kualitas tertentu yang harus disesuaikan oleh pegawai untuk dapat mengerjakannya sesuai ketentuan.Karyawan memiliki kinerja baik bila dapat menghasilkan pekerjaan sesuai persyaratan kualitas yang dituntut pekerjaan tersebut.

3. Ketepatan Waktu. Setiap pekerjaan memiliki karakteritas yang berbeda, untuk jenis pekerjaan tertentu harus diselesaikan tepat waktu, karena memiliki ketergantungan atas pekerjaan lainnya.

4. Kehadiran. Suatu jenis pekerjaan tertentu menuntut kehadiran pegawai dalam mengerjakan sesuai waktu yang ditentukan.Kinerja pegawai ditentukan oleh tingkat kehadiran pegawai dalam mengerjakannya. 
5. Kemampuan Kerja Sama. Tidak semua pekerjaan dapat diselesaikan oleh satu orang saja. Untuk jenis pekerjaan tertentu mungkin harus diselesaikan oleh dua orang atau lebih sehingga membutuhkan kerja sama antar pegawai sangat dibutuhkan. Kinerja pegawai dapat dinilai dari kemampuannya bekerja sama dengan rekan sekerja lainnya.

\section{Faktor-Faktor Yang Mempengaruhi Kinerja}

Menurut Mangkunegara (2006: 13), faktor-faktor yang mempengaruhi kinerja adalah:

1. Kemampuan (Ability). Kemampuan (ability) yang dimiliki karyawan bisa dikembangkan dan ditingkatkan melalui kegiatan pendidikan maupun pelatihan yang diberikan instansi tersebut, khususnya kemampuan yang dibutuhkan oleh instansi yang bersangkutan. Faktor kinerja terdiri dari faktor internal dan faktor ekternal. Faktor internal yaitu faktor yang dihubungkan dengan sifat-sifat seseorang. Misalnya kinerja seseorang baik disebabkan karena mempunyai kemampuan tinggi dan seseorang itu tipe pekerja keras, sedangkan seseorang mempunyai kinerja kurang baik disebabkan orang tersebut mempunyai kemampuan rendah dan orang tersebut tidak memiliki upaya-upaya untuk memperbaiki kemampuannya. Faktor eksternal yaitu faktor-faktor yang mempengaruhi kinerja seseorang yang berasal dari lingkungan seperti perilaku, sikap dan tindakan-tindakan rekan kerja, bawahan, pimpinan, fasilitas kerja dan iklim organisasi.

2. Motivasi (motivation). Kegairahan kerja pegawai akan meningkat apabila adanya motivasi, motivasi ini dapat berasal dari luar diri pegawai maupun dari dalam diri pegawai itu sendiri. Pemberian penghargaan pada pegawai merupakan suatu hal yang penting, sebab dengan adanya pemberian penghargaan tersebut diharapkan dapat merangsang serta dapat mendorong para pegawai mendapat atau mencapai sesuatu yang terbaik.Dengan demikian usaha-usaha yang menyangkut pemberian motivasi kepada pegawai seharusnya dilaksanakan dengan baik agar tidak terjadi kecenderungan sosial diantara pegawai. Hubungan antara pimpinan terjalin dengan baik apabila masing-masing menyadari apa yang telah menjadi tanggung jawab masing-masing dan menjadi kurang lengkap apabila salah satu pihak merasa tidak mendapatkan apa yang diharapkan, hubungan menjadi baik apabila terjadi kerjasama yang harmonis antara pimpinan dan bawahan.

\section{Penilaian Kinerja}

Penilaian kinerja mempunyai peran penting dalam peningkatan motivasi ditempat kerja. Penilaian kinerja ini (performance appraisal) pada dasarnya merupakan faktor kunci guna mengembangkan suatu organisasi secara efektif dan efisien. Pegawai menginginkan dan memerlukan umpan balik berkenaan dengan prestasi mereka dan 
penilaian menyediakan kesempatan untuk meninjau kemajuan pegawai dan untuk menyusun rencana peningkatan kinerja. Dengan peran yang dimiliki oleh para pegawai sebuah penggerak utama bagi setiap kegiatan dalam organisasi, tentunya untuk mengetahui seberapa jauh tingkat pencapaian tujuan yang telah didapat organisasi, diperlukan sebuah sistem penilaian terhadap kinerja pegawai. Hal ini merupakan suatu kegiatan yang dapat menggambarkan baik buruknya hasil sebuah organisasi dapat dilihat dengan jelas. Penilaian kinerja ini juga bermanfaat untuk organisasi agar dapat menentukan dengan tepat apa saja yangmereka perlu perbaiki oleh organisasi tersebut.

Menurut Bangun (2012:231), penilaian kinerja adalah proses yang dilakukan organisasi untuk mengevaluasi atau menilai keberhasilan karyawan dalam melaksanakan tugasnya. Penilain dapat dilakukan dengan membandingkan hasil kerja yang dicapai pegawai dengan standar pekerjaan.Penilaian kinerja dapat ditinjau kedalam jumlah dan kualitas pekerjaan yang diselesaikan pegawai pada periode tertentu. Kinerja seorang pegawai dapat dinilai berdasarkan jumlah pekerjaan yang diselesaikan dalam batas waktu tertentu. pegawai yang menyelesaikan pekerjaan dalam jumlah yang melebihi batas pekerjaan dinilai dengan kinerja yang kurang baik. Demikian juga, hasil pekerjaan yang kualitasnya melebihi dari standar dan pekerjaan tersebut diselesaikan tepat waktu dapat dinilai dari kinerja baik.

\section{Tujuan dan Manfaat Penilaian Kinerja}

Tujuan dan manfaat penilaian kinerja menurut Bangun (2012:233), yaitu:

1. Evaluasi Antar Individu Dalam Organisasi. Penilaian kinerja dapat bertujuan untuk menilai kinerja individu dalam organisasi. Tujuan ini dapat memberi manfaat dalam menentukan jumlah dan jenis kompensasi yang merupakan hak bagi setiap individu dalam organisasi. Kepentingan lain atas tujuan ini adalah sebagai dasar dalam memutuskan pemindahan pekerjaan (job transferring) pada posisi yang tepat, promosi pekerjaan, mutasi sampai tindakan pemberhentian.

2. Pengembangan dari Setiap Individu dalam Organisasi. Penilaian kinerja pada tujuan ini bermanfaat untuk pengembangan pegawai. Pegawai yang berkinerja randah disebabkan kurangnya pengetahuan atas pekerjaan-pekerjaanya akan lebih ditingkatkan pendidikannya, sedangkan bagi pegawai yang kurang terampil dalam pekerjaanya akan diberi pelatihan yang sesuai. 
3. Pemeliharaan Sistem. Tujuan pemeliharaan sistem akan memberi beberapa manfaat antara lain: pengembangan perusahaan dari individu, evaluasi pencapaian tujuan oleh individu atau tim, perencanaan sumbar daya manusia, dan identivikasi kebutuhan pengembangan organisasi dan audit atas sistem sumber daya manusia.

4. Dokumentasi. Penilaian kinerja akan memberi manfaat sebagai dasar tindak lanjut dalam posisi pekerjaan pegawai dimasa akan datang. Manfaat penilaian kinerja disini berkaitan dengan keputusan-keputusan manajemen sumber daya manusia, pemenuhan secara legal manajemen sumber daya manusia.

\section{Kriteria Penilaian Kinerja}

Kriteria penilaian menurut Bangun (2012:233), yaitu:

1. Kriteria Berdasarkan Sifat. Yaitu menyoroti tentang kepribadian pegawai yang berkaitan dengan loyalitas, pengetahuan, keterampilan, dan kemampuan pegawai.

2. Kriteria Berdasarkan Prilaku. Yaitu menyoroti tentang perilaku pegawai dalam melaksanakan pekerjaannya.

3. Kriteria Berdasarkan Hasil. Yaitu mengarah kepada jumlah pekerjaan dari pada kualitas pekerjaan

\section{Kerangka Pemikiran}

Dalam rangka mempermudah penyusunan karya ilmiah ini, maka dapat disusun kerangka pemikiran teoritis seperti pada Gambar 1

\section{Gambar 1}

Kerangka Pemikiran Teoritis

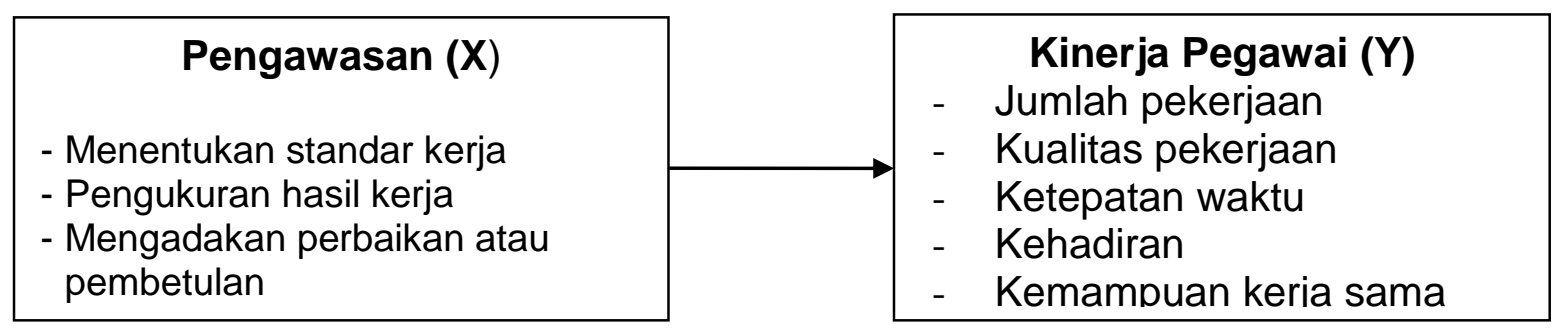

\section{Hipotesis Penelitian}

Hipotesis adalah suatu dugaan sementara terhadap permasalahan penelitian sampai terbukti kebenarannya. Berdasarkan perumusan masalah yang telah diuraikan diatas, maka dapat dirumuskan Hipotesis penelitian ini adalah Ada pengaruh positif dan signifikan antara pengawasan terhadap kinerja pegawai Kantor Camat Kecamatan Plakat Tinggi. 


\section{METODOLOGI PENELITIAN}

\section{Lokasi dan Waktu Penelitian}

Dalam penelitian ini penulis mengambil objek pada Kantor Camat Kecamatan Plakat Tinggi yang beralamatkan didesa Sidorahayu Kecamatan Plakat Tinggi Kabupaten Musi Banyuasin. Penelitian ini membutuhkan waktu selama dua bulan dari bulan januari sampai februari 2016.

\section{Metode Penelitian}

Menurut Subagyo (2006: 106), metode kuantitatif merupakan metode data dalam bentuk jumlah yang dituangkan untuk menentukan suatu penjelasan dari angka-angka atau menbandingkan beberapa gambar, baru kemudian dijelaskan kembali dalam bentuk kalimat atau uraian. Metode yang digunakan dalam penelitian ini adalah metode kuantitatif.

\section{Jenis dan Sumber Data}

Menurut Sugiyono (2009:138), jenis data yang diperlukan dalam penelitian adalah data primer. Data primer adalah data yang diperoleh dari hasil kuesioner dari responden penelitian yaitu pegawai yang ada dikantor Camat Kecamatan Plakat Tinggi

\section{Teknik Pengumpulan Data}

Subagyo (2006:37), menjelaskan ada beberapa prosedur pengumpulan data yang digunakan yaitu :

1. Studi Kepustakaan. Yaitu teknik pengumpulan data yang dilakukan dengan mempelajari masalah yang berhubungan dengan objek peneliti yang bersumber dari literatur-literatur yang berhubungan dengan peneliti dan penunjang atas dasar teori yang digunakan dalam permasalahan peneliti.

2. Studi Lapangan. Yaitu data yang dikumpulkan secara langsung dan melihat objek peneliti dilapangan sesuai dengan keadaan yang akan diteliti.

Penulis menggunakan teknik pengumpulan data yaitu dengan cara:

a. Kuesioner (Angket). Yaitu daftar pertanyaan yang disiapkan oleh peneliti dimana tiap pertanyaannya berkaitan dengan masalah penelitian.

b. Dokumen. Ditunjukkan untuk memperoleh data langsung dari peneliti, meliputi bukubuku yang relevan, laporan kegiatan, foto-foto datayang relevan. 
c. Observasi. Pengamatan langsung yang dilakukan oleh peneliti pada Kantor Camat Kecamatan Plakat Tinggi.

Adapun data yang digunakan dalam penelitian ini adalah data primer. Menurut Sanusi (2014:104), data primer adalah data yang pertama kali dicatat dan dikumpulkan oleh peneliti, penulis menggunakan kuesioner dilapangan atau lokasi penelitian agar mendapatkan data yang benar-benar aktual yang berhubungan dengan masalah yang akan diteliti.

\section{Populasi danTeknik Pengambilan Sampel}

Populasi menurut Sanusi (2014:87), adalah kumpulan elemen yang menunjukkan ciri-ciri tertentu yang dapat digunakan untuk membuat kesimpulan. Dalam penelitian ini teknik pengambilan sampelnya menggunakan sampling jenuh karna jumlah populasinya sedikit. Menurut Sugiyono (2009: 61), sampling jenuh adalah teknik penentuan sampel bila semua anggota populasi digunakan sebagai sampel. Dan jumlah populasi pada Kantor Camat Kecamatan Plakat Tinggi ini berjumlah 30 orang.

\section{Varibel Penelitian}

Variabel yang akan digunakan dalam peneltian ini adalah:

1. Variabel Bebas. Menurut Sanusi (2014:50), yaitu variabel yang mempengaruhi variabel lain. Variabel bebas dalam penelitian ini adalah pengawasan (X).

2. Variabel Terikat. Sanusi (2014:50), mendefinisikan variabel terikat adalah variabel yang dipengaruhi oleh variabel lain. Variabel dalam penelitian ini adalah kinerja (Y).

\section{Definisi Variabel Operasional}

Definisi variabel operasional pada penelitian ini dapat dilihat pada Tabel 1 berikut ini

\section{Tabel 1}

\section{Operasionalisasi Variabel Penelitian}

\begin{tabular}{|c|c|c|c|c|}
\hline No & Variabel & Definisi & Indikator & Skala \\
\hline 1. & $\begin{array}{c}\text { Pengawasan } \\
\text { (X) }\end{array}$ & $\begin{array}{l}\text { Menurut Siagian (2007: 55), pengawasan } \\
\text { adalah keseluruhan upaya pengamatan } \\
\text { pelaksanaan kegiatan operasional guna } \\
\text { menjamin bahwa kegiatan tersebut sesuai } \\
\text { dengan rencana yang telah ditetapkan }\end{array}$ & $\begin{array}{l}\text { 1. Menentukan standar } \\
\text { kerja } \\
\text { 2. Pengukuran hasil kerja } \\
\text { 3. Mengadakan perbaikan } \\
\text { atau pembetulan }\end{array}$ & Likert \\
\hline
\end{tabular}




\begin{tabular}{|l|c|l|l|l|}
\hline & & sebelumnya. & & \\
\hline 2. & Kinerja & Bangun (2012: 231), mendefinisikan & 1. Jumlah pekerjaan & Likert \\
& $(Y)$ & kinerja (performance) merupakan hasil & 2. Kualitas pekerjaan & \\
& pekerjaan yang dicapai seseorang & 3. Ketepatan waktu & \\
& berdasarkan persyaratan-persyaratan & 4. Kehadiran & \\
& pekerjaan. & 5. Kemampuan kerja & \\
& & sama & \\
\hline
\end{tabular}

\section{HASIL DAN PEMBAHASAN}

\section{Gambaran Umum Objek Penelitian}

Wilayah Kecamatan Plakat Tinggi semula merupakan bagian dari Wilayah Kecamatan Babat Toman, dengan dibentuknya Kecamatan Plakat Tinggi, maka Wilayah Kecamatan Babat Toman dikurangi. Berdasarkan surat keputusanbahwa dengan semakin meningkatnya jumlah penduduk dan volume kegiatan pemerintahan dan pembangunan diwilayah Kabupaten Musi Banyuasin, sehingga untuk memperlancar pelaksanaan tugastugas pelayanan dibidang pemerintahan dan pembangunan serta untuk meningkatkan pelayanan terhadap masyarakat, dipandang perlu membentuk Kecamatan Baru di Wilayah Kabupaten Musi Banyuasin. Berdasarkan surat keputusan ini Pada 25 Juli 2005 Kecamatan ini sudah lepas dari Kecamatan Babat Toman dan resmi menjadi kecamatan sendiri yaitu Kecamatan Plakat Tinggi dan Kantor Camat Plakat Tinggi ini berada diDesa Sidorahayu yang mempunyai wilayah seluas 247 kilometer persegi.

\section{Hasil Penelitian}

Hasil uji validitas dengan menggunakan metode Bivariate Pearson (Produk Momen Pearson) untuk item-item variabel independen dan dependen diperoleh nilai $\mathrm{r}$ hitung yang lebih besar dari $\mathrm{r}$ tabel yang berarti semua item pertanyaan variabel independen dan dependen dinyatakan valid. Hal ini digambarkan dalam Tabel 2 berikut: 
Tabel 2

Hasil Uji Validitas Variabel Pengawasan(X)

Dan Variabel Kinerja(Y)

\begin{tabular}{|c|c|c|c|c|}
\hline Variabel & Item Pernyataan & r-hitung & r-tabel & Hasil \\
\hline \multirow{6}{*}{ X-1 } & 0,572 & 0,361 & Valid \\
& X-2 & 0,718 & 0,361 & Valid \\
& X-3 & 0,568 & 0,361 & Valid \\
& X-4 & 0,620 & 0,361 & Valid \\
& X-5 & 0,479 & 0,361 & Valid \\
& X-6 & 0,561 & 0,361 & Valid \\
& X-7 & 0,680 & 0,361 & Valid \\
& X-8 & 0,538 & 0,361 & Valid \\
& X-9 & 0,618 & 0,361 & Valid \\
& X-10 & 0,579 & 0,361 & Valid \\
\hline \multirow{5}{*}{ Y-1 } & 0,622 & 0,361 & Valid \\
& Y-2 & 0,515 & 0,361 & Valid \\
& Y-3 & 0,554 & 0,361 & Valid \\
& Y-4 & 0,623 & 0,361 & Valid \\
& Y-5 & 0,612 & 0,361 & Valid \\
& Y-6 & 0,804 & 0,361 & Valid \\
& Y-7 & 0,728 & 0,361 & Valid \\
& Y-8 & 0,754 & 0,361 & Valid \\
& Y-9 & 0,560 & 0,361 & Valid \\
& Y-10 & 0,544 & 0,361 & Valid \\
\hline
\end{tabular}

Sumber : Data diolah (SPSS)

Hasil uji reliabilitas terhadap kuesioner pengawasan dan kinerja pegawai diperoleh cronbach's alpha tersebut diatas 0.60, sehingga dapat disimpulkan bahwa instrumen yang digunakan dinyatakan reliabel dan dapat dilihat pada Tabel 3 berikut ini:

Tabel 3

Hasil Uji Reliabilitas

\begin{tabular}{|l|c|c|}
\hline \multicolumn{1}{|c|}{ Variabel } & Cronbach Alpha & Kesimpulan \\
\hline Pengawasan $(\mathrm{X})$ & 0,787 & Reliabel \\
\hline Kinerja (Y) & 0,832 & Reliabel \\
\hline
\end{tabular}

Sumber: Data diolah (SPSS)

Analisis regresi linier sederhana menggunakan bantuan program SPSS (Statistical Product and Service Solution). Berdasarkan perhitungan program SPSS versi 17 diperoleh hasil sebagai berikut: 


\section{Tabel 4}

Hasil Regresi Linier Berganda

\begin{tabular}{|c|c|c|c|c|}
\hline \multirow[b]{2}{*}{ Model } & \multicolumn{2}{|c|}{ Unstandardized Coefficients } & \multirow[b]{2}{*}{$\mathrm{T}$} & \multirow[b]{2}{*}{ Sig. } \\
\hline & B & Std. Error & & \\
\hline 1 (Constant) & 6.478 & 4.880 & 1.327 & 195 \\
\hline Pengawasan $(\mathrm{X})$ & .846 & .124 & 6.808 & .000 \\
\hline
\end{tabular}

a. Dependent Variable: Kinerja (Y)

Sumber : Data diolah (SPSS)

Berdasarkan hasil perhitungan yang dilakukan diperoleh nilai a sebesar 6.478 dan nilai b sebesar 0.846. sehingga bentuk persamaan regresi linier sederhana sebagai berikut:

\section{$Y=6.478+0.846 X$}

Dari persamaan regresi sederhana tersebut mengenai pengaruh variabel independen (pengawasan) terhadap variabel dependen (kinerja pegawai) dapat dijelaskan sebagai berikut:

a. Nilai konstanta sebesar 6.478 menunjukkan bahwa jika pengawasan dianggap tidak ada (nol) maka kinerja pegawai sebesar 6.478.

b. Koefisien regresi variabel pengawasan (X) menunjukkan pengaruh positif sebesar0.846 terhadap kinerja (Y). Koefisien regresi bernilai positif menunjukkan pengaruh yang searah, artinya semakin tinggi nilai variabel pengawasan akan menyebabkan semakin tinggi kinerja pegawai. Sebaliknya semakin rendah nilai pengawasan, maka semakin rendah pula kinerja pegawai.

Analisis korelasi digunakan untuk mencari bukti ada tidaknya hubungan antar variabel, dalam hal ini variabel pengawasan (X) dengan kinerja (Y). Berikut ini dapat dilihat hasil perhitungan korelasi variabel pengawasan dan kinerja:

\section{Tabel 5}

\section{Koefisien Korelasi}

Model Summary

\begin{tabular}{|l|r|r|r|r|}
\hline Model & R & R Square & Adjusted R Square & Std. Error of the Estimate \\
\hline 1 & $.790^{\mathrm{a}}$ & .623 & .610 & 3.400 \\
\hline
\end{tabular}

a. Predictors: (Constant), X

Sumber : Data diolah (SPSS) 
Hasil analisis korelasi sederhana $\mathrm{R}$ digunakan untuk tinggi-rendah dan arah hubungan antara variabel X (pengawasan) dengan variabel Y (kinerja). Berdasarkan tabel diatas diperoleh nilai $\mathrm{R}$ ataukoefisien korelasi sebesar 0.790. Dari penafsiran terhadap data tersebut dapat diketahui bahwa terjadi hubungan positif yang sangat kuat antara pengawasan dan kinerja pegawai. Sedangkan nilai R2 (R Square) sebesar 0.623 menunjukkan bahwa variabel pengawasan mempengaruhi kinerja pegawai sebesar $62.3 \%$ sedangkan sisanya $37.7 \%$ dipengaruhi oleh variabel lain yang tidak diteliti dalam penelitian ini.

\section{Interpretasi Hasil Analisis}

Berdasarkan penelitian dan analisis yang dilakukan, maka dapat diinterpretasikan sebagai berikut:

1. Dari perhitungan analisis regresi linier sederhana, diperoleh persamaan regresi $\mathrm{Y}=$ $6.478+0.846 \mathrm{X}$ ini berarti pengawasan mempunyai pengaruh searah (positif) terhadap kinerja pegawai

2. Dari hasil analisis diperoleh data nilai $\mathrm{R}$ atau koefisien korelasi sebesar 0.790 bernilai positif. Artinya makin tinggi tingkat pengawasan maka makin tinggi pula tingkat kinerja pegawai. Nilai $\mathrm{R}$ squareatau koefisien determinasi sebesar 0.623 menunjukkan bahwa variabel pengawasan mempengaruhi kinerja pegawai sebesar $62.3 \%$ sedangkan sisanya $37.7 \%$ dipengaruhi oleh variabel lain yang tidak diteliti dalam penelitian ini.

\section{SIMPULAN DAN SARAN}

\section{Kesimpulan}

Berdasarkan uraian dan hasil analisis yang telah dikemukakan pada bab-bab terdahulu, maka hasil penelitian ini dapat disimpulkan sebagai berikut:

1. Berdasarkan uji validitas dan reliabilitas dapat disimpulkan bahwa seluruh item dalam variabel $\mathrm{X}$ (pengawasan) dan variabel $\mathrm{Y}$ (kinerja) dinyatakan valid dan reliabel sehingga dapat digunakan untuk mengukur intrumen dalam penelitian.

2. Berdasarkan uji regresi linier sederhana, bahwa terdapat pengaruh yang positif dan signifikan antara variabel $\mathrm{X}$ dan variabel $\mathrm{Y}$, hal ini ditunjukkan pada koefisien regresi atau nilai $b$ dalam persamaan regresi yang menunjukkan angka positif. $\mathrm{Y}=6.478+0.846 \mathrm{X}$ 
3. Berdasarkan uji korelasi, bahwa variabel $\mathrm{X}$ memiliki tingkat hubungan yang kuat terhadap variabel $\mathrm{Y}$, hal ini ditunjukkan dengan nilai $\mathrm{R}$ atau koefisien korelasi sebesar 0.790 bernilai positif, yang berarti bahwa variabel $\mathrm{X}$ memiliki tingkat hubungan yang kuat terhadap variabel $\mathrm{Y}$. Nilai R square atau koefisien determinasi sebesar 0.623 menunjukkan bahwa variabel pengawasan mempengaruhi kinerja pegawai sebesar $62.3 \%$ sedangkan sisanya $37.7 \%$ dipengaruhi oleh variabel lain yang tidak diteliti dalam penelitian ini.

4. Berdasarkan uji hipotesis, terbukti bahwa ada pengaruh yang signifikan antara varibel $\mathrm{X}$ (pengawasan) dengan variabel $\mathrm{Y}$ (kinerja) hal ini dapat dilihat dari nilai thitung sebesar 6.808 dengan signifikan 0.000. Berdasarkan hipotesis bahwa pengawasan berpegaruh signifikan terhadap kinerja pegawai kerena nilai signifikan $0.000<0,05$.

\section{Saran}

Berdasarkan hasil pembahasan dan kesimpulan penelitian ini, maka disarankan hal-hal sebagai berikut :

1. Bagi Pimpinan hendaknya dengan diketahui bahwa pengawasan mempunyai pengaruh yang signifikan terhadap kinerja pegawai pada Kantor Camat Plakat Tinggi maka disarankan agar pemimpin lebih meningkatkan pengawasannya dan memberikan sanksi kepada pegawai yang melanggar peraturan. Pemimpin sebaiknya lebih meningkatkan pengawasannya sehingga bisa mengetahui tinggi rendahnya kinerja pegawai.

2. Bagi pegawai diharapkan agar mentaati semua peraturan yang telah ditetapkan oleh Kantor Camat Plakat Tinggi sehingga akan mudah untuk mencapai tujuan instansi tersebut.

3. Untuk meningkatkan kinerja pegawai yang diharapkan, pimpinan hendaknya memperhatikan faktor apa saja yang menjadi pemicu untuk meningkatkan kinerja pegawai khususnya dari segi pegawasan yang dilakukan.

\section{DAFTAR PUSTAKA}

Bangun, Wilson. 2012. Manajemen Sumber Daya Manusia. Bandung: Erlangga.

Draft, L Richard. 2012. Era Baru Manajemen. Jakarta: Salemba Empat.

Engkoswara. 2011. Administrasi Pendidikan. Bandung: Alfabeta.

Handoko, T. Hani. 2009. Sumber Daya Manusia. Jakarta: Ghalia. 
Hasibuan, Melayu S.P. 2008. Manajemen Dasar, Pengertian Dan Masalah. Jakarta: PT Bumi Aksara.

Mangkunegara, Prabu Anwar. 2006. Evaluasi Kinerja Sumber Daya Manusia. Bandung: PT. Refika Aditama.

Rivai, Veithzal dkk. 2014. Manajemen Sumber Daya Manusia Untuk Perusahaan. jakarta: Rajawali Pers.

Sanusi, Anwar. 2014. Metodologi Penelitian Bisnis. Jakarta: Salemba Empat.

Siagian, P Sondang. 2007. Manajemen Sumber Daya Manusia. Jakarta: PT.Bumi Aksara.

Solihin, Ismail. 2009. Pengantar Manajemen. Jakarta: Erlangga.

Subagyo, P Joko. 2006. Manajemen Penelitian Dalam Teori Dan Praktek. Jakarta: Rieneke Cipta.

Sugiyono. 2009. Metode Penelitian Bisnis. Bandung: Alfabeta.

Sutrisno, Edi. 2013. Manajemen Sumber Daya Manusia. Jakarta: Kencana Prenada Media Group.

Tika, Moh. Pabundu. 2006. Budaya Organisasi Dan Peningkatan Kinerja Perusahaan. Jakarta:PT.Bumi Aksara 